\title{
Biodiversity evolution through the Permian-Triassic boundary event: Ostracods from the Bükk Mountains, Hungary
}

Marie-Béatrice Forel, Sylvie Crasquin, Kinga Hips, Steve Kershaw, Pierre-Yves Collin, and János Haas Acta Palaeontologica Polonica 58 (1), 2013: 195-219 doi: http://dx.doi.org/10.4202/app.2011.0126

One of the most complete Permian-Triassic boundary sections located in the Bükk Mountains (Hungary) was sampled for ostracod study. Seventy-six species are recognized, belonging to twenty genera. Fifteen new species are described and figured: Acratia? jeanvannieri Forel sp. nov., Acratia nagyvisnyoensis Forel sp. nov., Bairdia anisongae Forel sp. nov., Bairdia davehornei Forel sp. nov., Callicythere? balvanyseptentrioensis Forel sp. nov., Cytherellina? magyarorszagensis Forel sp. nov., Eumiraculum desmaresae Forel sp. nov., Hollinella fengqinglaii Crasquin sp. nov., Hungarella gerennavarensis Crasquin sp. nov., Langdaia bullabalvanyensis Crasquin sp. nov., Liuzhinia venninae Forel sp. nov., Liuzhinia bankutensis Forel sp. nov., Microcheilinella egerensis Forel sp. nov., Reviya praecurukensis Forel sp. nov., Shemonaella? olempskaella Forel sp. nov. One species is renamed: Bairdia baudini Crasquin nom. nov. Comparison of the Bálvány North section with the Meishan section (Zhejiang Province, South China), Global Boundary Stratotype Section and Point (GSSP) of the Permian-Triassic Boundary (PTB), reveals discrepancies linked to the environmental setting and particularly to bathymetry. The stratigraphical distribution of all the species is given and diversity variations are discussed. The Bálvány North section exhibits the lowest extinction rate of all PTB sections studied for ostracods analysis associated with a high level of endemism.

Key words: Ostracoda, biodiversity, Permian-Triassic boundary, Bükk Mountains, Hungary.

Marie-Béatrice Forel [mbforel@yahoo.fr], State Key Laboratory of Geological Process and Mineral Resources, China University of Geosciences, Wuhan Hubei, People's Republic of China; Sylvie Crasquin [sylvie.crasquin@upmc.fr], CNRS - UMR 7207 CR2P, UPMC Univ. Paris 06, Laboratoire de Micropaléontologie, T.46-56, E.5, case 104, 75252 Paris cedex 05, France; Kinga Hips [hips@1udens.elte.hu] and János Haas [haas@ludens.elte.hu], Geological, Geophysical and Space Science Research Group, Hungarian Academy of Sciences, Eötvös University, H-1117 Budapest, Pázmánys; 1/c, Hungary; Steve Kershaw [stephen.kershaw@brunel.ac.uk], Institute for the Environment, Halsbury Building, Brunel University, Uxbridge, Middlesex, UB8 3PH, UK; Pierre-Yves Collin [pierre-yves.collin@u-bourgogne.fr], Université de Bourgogne, UMR 6282 Biogéosciences, Bât. Sciences Gabriel, 6 Bd Gabriel, 21000 Dijon, France. 
This is an open-access article distributed under the terms of the Creative Commons Attribution License (for details please see creativecommons.org), which permits unrestricted use, distribution, and reproduction in any medium, provided the original author and source are credited.

FaF $\underline{\text { Full text }(1,938.1 \mathrm{kB})}$ 